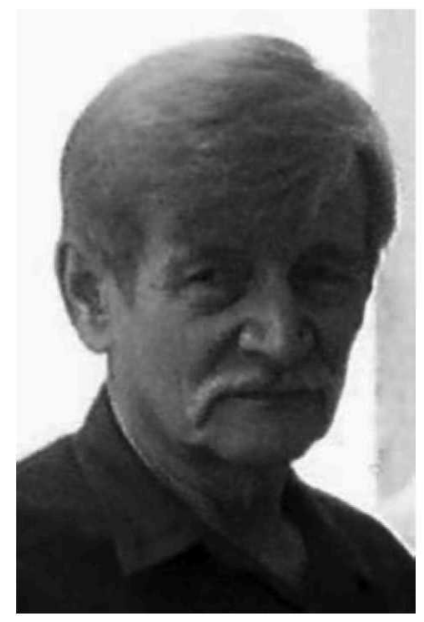

\title{
Niilo Eelis Virkki, Cytogeneticist: In Memoriam (1924-2005) ${ }^{1}$
}

Which weeps the comrade of my choice, An awful thought, a life removed, The human-hearted man I loved, A Spirit, not a breathing voice.

by Alfred, Lord Tennyson (1809-1892)

\section{Alejandro E. Segarra-Carmona ${ }^{2}$, Jorge A. Santiago-Blay ${ }^{3}$ and Jaime Escudero ${ }^{4}$}

\section{J. Agric. Univ. P.R. 92(3-4):245-256 (2008)}

Dedication, persistence and devotion to science, and to all things alive, marked Niilo Virkki's work until illness overtook him 10 September 2005, in his adoptive Puerto Rico. His wife Sylvi, his daughters

${ }^{1}$ Manuscript submitted to Editorial Board 7 February 2008.

${ }^{2}$ University of Puerto Rico Agricultural Experiment Station. Direct all correspondence to the senior author. Email: asegarra@uprm.edu.

${ }^{3}$ Department of Paleobiology. National Museum of Natural History, Smithsonian Institution. Washington. D.C.

${ }^{4}$ University of Puerto Rico Agricultural Experiment Station. 
Jaana and Anna, and son Jyri survive him. Virkki spent 45 years in Puerto Rico, where he worked as a Cytogeneticist at the University of Puerto Rico, Agricultural Experiment Station between 1961 and 1995. His highly productive career and his legacy of scientific work in cytogenetics are recognized worldwide. Of note, his pioneering work with the Oedionychina (Coleoptera: Chrysomelidae), especially with the beautiful metallic-colored Alagoasa beetles, made him the world authority in coleopteran cytogenetics. During his life, Dr. Niilo Virkki authored or coauthored over a hundred peer-reviewed articles as well as several book chapters.

Niilo Virkki was born 7 May 1924 in Vouksela, in the magnificent Karelia region of eastern Finland (annexed by Russia during WWII). As a child, he loved cross-country skiing in the crisp air of Finnish winters. He often spoke of early awakenings of his love for nature through this childhood fondness for his country's forests and for his people. As a young man, he also endured the horrors of World War II as the conflict enveloped and shattered his beloved land. Perhaps war, and the cruel and terrifying Nazi and Soviet occupations that followed, helped in forging a man possessing his relentless and purposeful character. Adversity did not stop Niilo Virkki from being a man with endless love, wonderment and compassion for other people, and for having passion for the natural world around him.

After the war, Virkki studied at the University of Helsinki's Department of Mathematics and Natural History. Here he obtained these degrees: Candidate of Philosophy (1949, Major: Genetics); Licentiate of Philosophy (1951, Majors; Genetics and Zoology); and a Doctor of Philosophy in Cytogenetics (1952). While at school he worked as veterinary inspector for the City of Helsinki's Health Board. In 1951, he obtained a full time award for basic studies in insect cytology from the Finnish government, which enabled him to complete his doctoral research. After his graduation, he worked at the University of Helsinki until 1959, becoming Associate Professor of Genetics. In 1956, the Canadian Department of Agriculture awarded him a postgraduate fellowship at the Ottawa Forest Insect Laboratory, where he worked under the direction of Dr. S.G. Smith. In 1959, he obtained a joint appointment by the Universities of Helsinki and El Salvador, under the prestigious Rosenberg Award, to survey insect chromosomes in Central America.

In 1961, Arturo Roque then Director of the UPR Agricultural Experiment Station hired him as an Assistant Cytogeneticist at the Department of Genetics in Río Piedras. In 1981, Dr. Virkki took sabbatical leave to work at the Centro do Genética at Universidade Estadual Paulista in Campinas, Brazil. Collections he made in the Amazon basin formed the basis of several publications, even though he lost many cy- 
togenetic preparations and samples to careless custom agents and would-be jewel thieves.

Niilo Virkki devoted much of his work to karyotypic descriptions and gametogenesis studies of both insects and plants. In most of his work he concentrated on cytogenetic and cytotaxonomic studies of fleabeetles (Chrysomelidae: Galerucinae: Alticini) from Neotropical regions, especially from Puerto Rico and from Brazil. For his outstanding and original work he was invited to collaborate with several internationally renowned organizations, such as the Max Planck- Institut für Zellbiologie Abteilung in Tübingen, Germany; the North American Treaty Organization's (NATO's) Advanced Studies Institute in Stressa, Italy; the Universidad Nacional de Cuzco in Perú; Oregon State University, Corvallis, Oregon; Duke University, North Carolina; the University of Pennsylvania's J. Leidy Institute in Philadelphia; and the Waksman Institute of Microbiology at Rutgers University in New Jersey.

Dr. Virkki's important discoveries in chrysomelid cytogenetics made him a world-renowned scientist worthy of profound admiration and recognition. His most noted discoveries and accomplishments include: (1) the discovery of the smallest karyotype and meiotype in the Coleoptera; (2) the discovery and interpretation of unorthodox and interesting modes of chromosome orientation and segregation in Neotropical Alticini; (3) the presentation of novel hypotheses of quantitative aspects of centromere function; (4) the discovery of correct timing of gametogenesis in controlling irradiation results or the "irradiation clock" for the sugarcane borer, Diatraea saccharalis (Lepidoptera: Pyralidae); (5) the discovery and assessment of environmental controls for evaluating plant gametogenesis in sugarcane; (6) the cytological description of seven color morphs of the Puerto Rican sugarcane weevil, Diaprepes abbreviatus (L.) (Coleoptera: Curculionidae); and (7) the preparation of the first comprehensive synopsis of cytogenetic variables and descriptions for the abundant and important Chrysomelid beetle fauna of Puerto Rico (Table 1). A list of science publications by Dr. Niilo Virkki is shown in Table 2. 'Don Niilo', as many affectionately called him, was also an ardent woodworker in his spare time; he specialized in making high quality furniture and sports-fishing rods.

Finally, Dr. Niilo Virkki was a profound observer of nature and people. At the University of Puerto Rico he trained and befriended all those who came around him, including students, co-workers, and colleagues. His broad smile and his sweet sense of humor overcame every obstacle and sadness that befell those who knew him. The scientific world has lost one of its best, a real credit to the creative genius of his native Finland, a true friend, and an indefatigable discoverer of natural wonders in Puerto Rico and in the world. 
TABLE 1.-List of Puerto Rican Coleoptera: Chrysomelidae that Dr. Niilo Virkki described karyotypically (1964-1998). Species are listed by chrysomeline subfamily and tribe. (For complete records see Virkki \& Santiago-Blay, 1998)

\section{Criocerinae}

Lema dorsalis (Olivier)

Lema nigripes (Weise)

\section{Cryptocephalinae}

Pachybrachis mendica Weise

Cryptocephalus multiguttatus Suffrian

Cryptocephalus tristiculus Weise

Diachus nothus (Weise)

Exema carinaticollis (Lacordaire)

Chlamisus straminea Suffrian

\section{Lamprosomatinae}

Oomorphus longifrons (Lacordaire)

\section{Eumolpinae}

Alethaxius near meliae Blake Metachroma ampilicollis Blake Metachroma fenestratum Blake Metachroma leiotrachelus Blake Chalcosicya crotonis (Fabricius) Myochrous portoricensis Blake

\section{Chrysomelinae}

Leucocera laevicollis Weise

\section{Galerucinae}

Yingaresca varicornis (Weise)

Erynephala near maritima LeConte Neolachmaea obliterata (Olivier)

Diabrotica graminea Baly Acalymma annulata (Suffrian) Acalymma innuba (Fabricius) Acalymma bivittata (Fabricius) Ceratoma ruficornis Olivier

\section{Galerucinae: Alticini}

Disonycha spilotrachela Blake

Disonycha comma White

Disonycha leptolineata Blatchley

Disonycha eximia Harold

Pseudodisonycha portoricensis Blake Omophoita albicollis Fabricius Omophoita cyanipennis Fabricius
Alagoasa bicolor Linnaeus

Phyllotreta guatemalensis Jacoby

Aphthona lamprocyanea Blake

Glyptina sp.

Homoschema obesum Blake

Homoschema nigriventre Blake

Homoschema fraternum Blake

Homoschema latitarsum Blake

Apraea portoricensis Blake

Longitarsus oakleyi Blake

Longitarsus near varicornis Blake

Longitarsus sp.

Phyllotrupes near acutangula Chevrolat

Cyrsylus volkameriae (Fabricius)

Systena basalis Jacquelin DuVal

Syphraea cubana (Bryant)

Syphraea cylindrica (Weise)

Syphraea near maldonadoi (Blake)

Macrohaltica jamaicensis (Fabricius)

Lysathia ludoviciana (Fall)

Lysathia occidentalis Suffrian

Nesaecrepida rufomarginata Blake

Strabala puertoricensis Blake

Epitrix cucumeris (Harris)

Epitrix fasciata Blatchley

Chaetocnema brunnescens Horn

Heikertingerella krugi (Weise)

Aedmon eugeniae (Blake)

Aedmon morrisoni (Blake)

Aedmon oakleyi (Blake)

\section{Hispinae}

Sceloenopla mantecada Sanderson Chalepus sanguinicollis (Linnaeus) Hilarocassis exclamationis (Linnaeus)

Chelymorpha multipunctata Olivier

Physonota jamaicensis (Linnaeus)

Agroiconota propinqua (Boheman)

Deloyala guttata (Olivier)

Charidotella quadrisignata (Boheman)

Charidotella sexpunctata (Fabricius) 


\section{TABLE 2.-List of science publications by Dr: Niilo Virkki. 1951-1998.}

Virkki, N., 1951. Zur zytologie einiger Scarabaeiden (Coleoptera). Studien and der Spermatogenese. Ann. Zool. Soc. "Vanamo" 14:1-104.

Virkki, N., 1953. Über die Verknöcherung einiger Schädelsuturen beim Eichhörnchen, Sciurus vulgaris L. Arch. Soc. "Vanamo" 7:83-93.

Virkki, N., 1953. Suomalaisen oravan Pääkallon mitoista.Arch. Soc. "Vanamo" 7:94-99.

Virkki, N., 1953. Versuch einer Kernanalyse bei den somatischen Hodenzellen der Aphodius-Arten (Coleoptera, Scarabaeidae). Chromosoma 6:1-32.

Virkki, N., 1954. Weitere Spermatogenesestudien an Skarabäiden (Coleoptera). Ann. Acad. Sci. Fenn. A. IV 25:1-58.

Virkki, N., 1954. Akzessorische Chromosomen bei zwei Käfern, Epicometis hirta Poda und Oryctes nasicornis L. Ann. Acad. Sci. Fenn. A. IV 26:1-19.

Virkki, N., 1954. Über den Schaltknochen der Bregmagegend beim Eichhörnchen, Sciurus vulgaris L. Arch. Soc. "Vanamo" 9:100-108.

Virkki, N., 1955. Mitose und meiose. Nuturwiss. Rundschau 8:352-355.

Virkki, N., 1956. Zur Kenntnis der postmeiotischen Ereignisse der Samenentwicklung bie der Skarabäiden (Coleoptera). Canad. J. Zool. 35:265-277.

Virkki, N., 1957. Bregmaknochen im Schädel nordamerikanischer Eichhörnchen. Arch. Soc. "Vanamo" 11:187-188.

Virkki, N., 1957. Structure of the testis follicle in relation to evolution in the Scarabaeidae (Coleoptera). Canad. J. Zool. 35:265-277.

Virkki, N., 1958. Chiasma relations in an elaterid beetle,Agriotes mancus Say. Proc. $10^{\text {th }}$ International Congr. Entomol. Montreal 2:953-959.

Virkki, N., 1958. High chiasma frequency in allocyclic segments of chromosomes. Nature 181:1146-1147.

Virkki, N., 1959. Neo-XY mechanism in two scarabaeoid beetles, Phanaeus vindex MacL. (Scarabaeidae), and Dorcus parallelopipedus L. (Lucanidae). Hereditas 45:481-494.

Virkki, N., 1959. Citología de algunos escarabajos neárticos (Coleoptera, Scarabaeidae). Comm. I.T.I.C. 8:40-49.

Virkki, N., 1960. Cytology of some Nearctic scarabs. (Coleoptera, Scarabaeidae) Ann. Acad. Sci. Fenn. A. IV 48:1-12.

Virkki, N., 1960. Cytology of male meiosis in certain European forest beetles of the families Scolytidae, Cleridae, Anobiidae. Ann. Acad. Sci. Fenn. A. IV 49:116.

Virkki, N., 1961. Salvadorin Instituto Tropical. Vousikymmen Luonnontutkimusta Keski-Amerikan pienimmässä tasavallassa. Luonnon Tutkija 65:5-9. 
Virkki, N., 1961. Non-conjugation and late conjugation of the sex chromosomes in the beetles of the genus Alagoasa. (Chrysomelidae, Alticinae). Ann. Acad. Sci. Fenn. A. IV 54:1-22.

Virkki, N., 1961. Talamancan pilvimetsissä ja paramoilla. Luonnon Tutkija 65:129-139.

Virkki, N., 1962. The passalid testis and its structural kinship with the testes of other scarabeoid beetles. Ann. Soc. "Vanamo" 16:19-22.

Virkki, N., 1962. Chromosomes of certain meloid beetles from El Salvador.Ann. Acad. Sci. Fenn. A. IV. 57:1-11.

Virkki, N., 1962. Meiosis and development of embryo sac in Gunnera insignis (Oersted) D.C. (Halorhagacease). J. Agric. Univ. P. R. 46:254-268.

Virkki, N., 1962. On the cytology of some Neotropical elaterids (Coleoptera), with special reference to the Neo-XY of Pyrophorini. Ann. Acad. Sci. Fenn. A. IV. 61:1-21.

Virkki, N., 1962. Comentarios sobre el baño de vapor entre los indígenas de Guatemala. Revista Guatemala Indigena 2(2) :abril-junio.

Virkki, N., 1963. On the cytology of certain Neotropical Cantharoids. Ann. Acad. Sci. Fenn. A. IV. 65:1-16.

Virkki, N., 1963. Gametogenesis in Diatraea saccharalis (Fabr.). J. Agric. Univ. P. R. 47:57-59.

Virkki, N., 1963. Eighteen chromosome pairs in an American bamboo. Chusquea subtessellata Hitch. J. Agric. Univ. P. R. 47:98-101.

Virkki, N., 1963. Gametogenesis in the sugarcane borer moth, Diatraea saccharalis (Fabr.) (Crambidae). J. Agric. Univ. P. R. 47:102-137.

Virkki, N., 1963. High chromosome number and giant, postreductional sex chromosomes in Walterianella venusta Schaufuss (Chrysomelidae, Alticinae). J. Agric. Univ. P. R. 47:154-163.

Virkki, N., 1964. The chromosomes of Chironja. J. Agric. Univ. P. R. 48:13-16.

Virkki, N., 1964. On the cytology of some Neotropical Chrysomelidae (Coleoptera).Ann. Acad. Sci. Fenn. A IV. 75:1-25.

Virkki, N., 1964. Chromosomes of certain anthribid and brentid beetles from El Salvador. Ann. Acad. Sci. Fenn. A IV. 83:1-11.

Virkki, N., 1965. Insect gametogenesis as a target. Agric. Sci. Review 3:24-37.

Virkki, N. and C. Purcell. 1965. The lowest chromosome number in Coleoptera. J.Agric. Univ. P. R. 49:386-387.

Virkki, N. and C. Purcell. 1965. Four pairs of chromosomes: The lowest number in Coleoptera. J. Heredity. 56:71-74. 
Virkki, N., 1966. Observations on the spermatogenesis of some scarabaeoid beetles. J. Agric. Univ. P. R. 50:338-341.

Purcell, C. M. and N. Virkki, 1966. Two Trox karyotypes differing radically in the location of centromeres. J. Agric. Univ. P. R. 50:158-160.

Virkki, N., 1967. Chromosome relationships in some North American scarabaeoid beetles, with some special reference to Pleocoma and Trox. Canad. J. Genet. Cytol. 9:107-125.

Virkki, N., 1967. Initiation and course of male meiosis in scarabaeoid beetles, with special reference to Pleocoma and Lichnanthe. Pan-Pacific Entomol. 43:99-112.

Virkki, N., 1967. Orientation and segregation of asynaptic multiple sex chromosomes in the male of Omophoita clerica Erichson (Coleoptera, Alticidae). Hereditas 57:275-288.

Virkki, N. and C. M. Purcell, 1967. Observations on the behavior, genetics, and cytology of two South African Digitaria valida Stent accessions in Puerto Rico. J. Agric. Univ. Puerto Rico 51:258-269.

Virkki, N., 1968. Rapid allocyclic changes in the centric and an arm segment of the X chromosome of Omophoita superba Weise (Coleoptera, Alticidae). Hereditas 58:262-264.

Virkki, N., 1968. Regular segregation of seven asynaptic sex chromosomes in Asphaera daniela Bech. (Coleoptera, Alticidae). Caryologia 21:47-51.

Virkki, N., 1968. A chiasmate sex quadivalent in the male of an alticid beetle, Cyrsylus volkameriae (F.). Canad. J. Genet. Cytol. 10:898-907.

Virkki, N., D. W. Walker, and C. L. Rodríguez, 1969. Excision of gonads from immature Diatraea. Ann. Entomol. Soc. Amer: 62:457-458.

Virkki, N., 1969. Sperm bundles and phylogenesis. Zeitschr. Zellf. 101:13-27.

Virkki, N., 1970. Sex chromosomes and karyotypes of the Alticidae (Coleoptera). Hereditas 64:267-282.

Virkki, N., 1970. Alticids with 128 sperm cells per bundle. J. Agric. Univ. P. R. 54:586-587.

Virkki, N., 1970. Karyotype rearrangements and malformation of gonads in the walkingsticks (Phasmatoptera) of El Verde irradiation area. In: The Rainforest. Ed. E.S. Scott. pp 952-962.

Virkki, N., 1971. Formation and maintenance of the distance sex bivalent in Oedionychina (Coleoptera, Alticidae). Hereditas 68:305-312.

Virkki, N., 1972. Orientación y segregación de los cromosomas sexuales de los Alticidae. Folia Entom. Mexicana 98:23-24.

Virkki, N., 1972. Evolución del número de espermatozoo por fascículo en los insectos. Folia Entom. Mexicana 98:23-24. 
Virkki, N., 1972. Contraction stage and formation of distance sex bivalent in Oedionychina (Coleoptera, Alticidae). Hereditas 71:259-288.

Virkki, N. and P. Reyes-Castillo, 1972. Cytotaxonomy of Passalidae (Coleoptera).Ann. Esc. Nacional Cien. Biol. Mexico 19:49-83.

Virkki, N. and P. Reyes-Castillo, 1972. Citotaxonomía de Passalidae. Folia Entom. Mexicana 99:23-24.

Virkki, N., 1973. Evolution of sperm cell number per bundle in insects. Ann. Esc. Nacional Cien. Biol. Mexico 20:23-24.

Virkki, N., 1973. Meiotic orientation and segregation of asynaptic sex chromosomes in Alticidae (Coleoptera). Ann. Esc. Nacional Cien. Biol. Mexico 20:3551.

Virkki, N., 1973. Spermatogonial budding in fleabeetles. Caryologia 26:405423.

Virkki, N., 1974. Evolution of extremely complicated sex chromosome systems in Blaps (Coleoptera). J. Agric. Univ. P.R. 58:661-674.

Virkki, N., 1974. The Bouquet. J. Agric. Univ. P.R. 58:338-350.

Virkki, N., 1974. Brief notes on the cytology of Neotropical Coleoptera. 1. Colaspis tricolor Perty (Chrysomelidae: Eumolpinae: Colaspini). J. Agric. Univ. P.R. 59:305-306.

Escudero, J. and Virkki, N., 1976. On the cytology of Umbonia crassiconis (Amyot \& Serville) (Homoptera: Membracidae: Hoplophorioninae). J. Agric. Univ. P.R. 60(2):238-47.

Virkki, N., 1976. Prophase of spermatocyte I in Oedionychina (Coleoptera). J.Agric. Univ. P.R. 60:661-674.

Virkki, N., 1977. Brief notes on the cytology of Neotropical Coleoptera. 1.Apate monacha F. (Bostrychidae). J. Agric. Univ. P.R. 61:519-520.

Virkki, N., 1977. Clustering of nuclear pores to "nuclear sieves" in some Oedionychina fleabeetles. Trib. Inf. Bull. 20:143.

Virkki, N., 1978. Evolutionary aspects of the nucleolar association of sex chromosomes in male meiosis of Coleoptera. p. 280. In. XIV Internat. Congr. Genet., Moscow. 1978. Contrib. Pap. Sess. I. Publ. Office NAUK, Moscow. 307 pp.

Virkki, N., 1978. Pre-reduction of the X chromosome in Lycidae (Coleoptera: Cantharoidea). Genetica (Dordrecht) 49(2-3):229-232

Smith, S. G. and N. Virkki, 1978. Insecta. 5. Coleoptera. In: Animal Cytogenetics. Vol. 3. Ed. B. John. Berlin-Stuttgart. 376 pp.

Virkki, N. and M. Kimura, 1978. Distribution of nuclear pores and perinuclear dense substances in spermatocytes I of some Oedionychina flea beetles. Bio Systems 10:213-225. 
Virkki, N., 1979. Pre-reduction of X chromosome in Lycidae (Coleoptera: Cantharoidea). Genetica 49:229-232.

Virkki, N., 1979. Ovariole numbers in two Puerto Rican Oedionychina (Coleoptera). J. Agric. Univ. P.R. 63:50-56.

Virkki, N., 1979. Brief notes on the cytology of Neotropical Coleoptera. III. " $L u$ perodes antillarum Blake" = Lysathia ludoviciana (Fall) J. Agric. Univ. P.R. 63:100-101.

Virkki, N., 1979. Response of an Oedionychina (Coleoptera) karyotype to acute gamma radiation. J. Agric. Univ. P.R. 63:116-145.

Virkki, N., 1980. Fleabeetles, especially Oedionychina, of a Puerto Rican marshland in 1969-72. J. Agric. Univ. P.R. 64:63-92.

Virkki, N., 1980. Katsaus hyonteissytogenetiikan tilaan Latinalaisessa Amerikassa. (Current position of insect cytogenetics in Latin America). Luonnon Tutkija 84:179-184.

Virkki, N. and I. Zambrana, 1980. Demes of a Puerto Rican fleabeetle, Alagoasa bicolor (L.), differing in mean body size and food plant association. $J$. Agric. Univ. P.R. 64:264-274.

Virkki, N. and I. Zambrana, 1983. Life history of Alagoasa bicolor (L.) in indoor rearing conditions (Coleoptera: Chrysomelidae: Alticinae). Ent. Arb. Mus. Frey 31/32:131-155, 21 figs.

Virkki, N., 1983. Banding of Oedionychina (Coleoptera: Alticinae) chromosomes: C- and Ag- bands. J. Agric. Univ. P.R. 67:221-255.

Virkki, N., 1983. Further chrysomelids with an X + Y sex chromosome system: Megalopodinae. Hereditas 98:209-213.

Virkki, N., M. Flores, and J. Escudero, 1984. Structure, orientation, and segregation of the sex trivalent in Pyrophorus luminosus Ill. (Coleoptera: Elateridae). Can. J. Genet. Cytol. 26:326-330.

Virkki, N., 1984. Additional observations on the life history of the Oedionychina fleabeetles: Alagoasa januaria Bechyne`. J. Agric. Univ. P. R. 68:1107109.

Virkki, N., 1984. Chromosomes in evolution of Coleoptera. pp. 41-76. Sharma, A.K.; Sharma, A. [Eds]. Chromosomes in evolution of eukaryotic groups. Volume 2. CRC Press Inc., USA. 269 pp.

Flores, M., A. Denton, and N. Virkki, 1984. Chromosomes of Sphictyrtus whitei (Guerin-Meneville) (Hemiptera: Coreidae). CIS Chromosome Information Service 15-17 No. 37

Ferreira, A., D M. Cella, A. Mesa, and N. Virkki, 1984. Cytology and systematical position of stylopids Strepsiptera. Hereditas 100(1):51-52

Ferreira, A., D. Cella, J. R. Tardivo, and N. Virkki, 1984. Two pairs of chromosomes: a new low record for Coleoptera. Brazilian J. Genetics 7(2):231-239 
Virkki, N., M. Flores and J. Escudero, 1984. Structure orientation and segregation of the sex trivalent in pyrophorusluminosus Coleoptera Elateridae. Can. J. Genetics and Cytology 26(3):326-330

Virkki, N. and M. C. Mazzella, 1984. Silver staining of the sex parachutes of some polyphagan beetles. Proceedings of the International Congress of Entomology 17:391.

Virkki, N., 1985. Chromosomes in evolution of Coleoptera. In: Chromosomes in the evolution of eukaryotic groups. Sharma, K. and A. Sharma. Eds. Vol. ii pp. 41-76. CRC Press. Florida. USA.

Virkki, N., 1985. The cytogenetic system of Oedionychina (Alticinae). Entomography 3:489-497.

Virkki, N. and A. Denton, 1987. Silver staining of the elements of spermatogenesis in Oedionychina (Chrysomelidae: Alticinae). Hereditas 106:37-49.

Virkki, N. and A. Denton, 1987. Brief notes on the cytology of Neotropical Coleoptera. 4. Chalcolepidius silbermanni Chevrolat (Elateridae: Pyrophorini). J. Agric. Univ. P.R. 71:323-326.

Virkki, N., T. Bruck, and A. Denton, 1987. Brief notes on the cytology of neotropical Coleoptera. 5. Storage and activation of large sperm cells in male Alticinae. J. Agric. Univ. P.R. 71:415-417.

Hantula, J., A. Saura, J. Lokki and N. Virkki, 1987. Genic and color polymorphism in Puerto Rican phyllobiine weevils Diaprepes abbreviatus (L.) and Compsus maricao Wolcott. J. Agric. Univ. P.R. 71:391-397.

Virkki, N., 1988. Cytotaxonomy of Alticinae. pp. 187-203. In: P. Jolivet, E. Petitpierre, \& T. H. Hsiao (Eds.). Biology of Chrysomelidae. Kluwer Acad. Publ. The Netherlands. 615pp.

Petitpierre, E., C. Segarra, J. S. Yadav and N. Virkki, 1988. Chromosome numbers and meioformulae of Chrysomelidae. pp. 161-186.In: P. Jolivet, E. Petitpierre, \& T. H. Hsiao (Eds.). Biology of Chrysomelidae. Kluwer Acad. Publ. The Netherlands. 615 pp.

Virkki, N., 1988. The sex chromosomes of Disonycha (Coloptera; Alticinae): Xy $+\mathrm{nX}$ systems. Cytobios 53:43-55.

Virkki, N., 1989. On the cytological justification of the flea beetle subtribes Oedionychina and Disonychina (Bechyne and Springlova de Bechyne 1966). Entomography 6:545-550.

Virkki, N., 1989. Proximal vs. distal collochores in Coleopteran chromosomes. Hereditas 110:101-107.

Santiago-Blay, J. A. and N. Virkki, 1989. On the XO sex chromosome system of Aulacoscelis melanocera Stål (Aulacoscelinae: Chrysomelidae: Coleoptera). Hereditas 111:99-102. (Erratum: Duponchel and Chevrolat, not Stål described, this species.) 
Virkki, N., W. Figueroa and J. M. Sepúlveda, 1989. Howardula sp., a nematode new for Puerto Rico, parasitizing a parthenogenetic sweet potato-associated flea beetle, Chaetocnema perplexa Blake. J. Agric. Univ. P.R. 73:171-174.

Virkki, N and J. M. Sepúlveda, 1990. Chromosomes of the Puerto Rican 'vaquita,' Diaprepes abbreviatus (L.) (Curculionidae: Otiorrhynchinae: Phyllobiini). J. Agric. Univ. P.R. 74:121-132.

Virkki, N., C. Mazzella and A. Denton, 1990. Staining of substances adjacent to the sex bivalent in certain weevils of Puerto Rico. J. Agric. Univ. P.R. 74:405418.

Virkki, N., 1990. What happens in the clump stage of spermatogenesis? Nucleus 33:41-43.

Virkki, N., C. Mazzella and A. Denton, 1991. Silver staining of the coleopteran $\mathrm{Xy}_{\mathrm{p}}$ sex bivalent. Cytobios 67:45-63.

Virkki, N., J. A. Santiago-Blay and S. M. Clark, 1991. Chromosomes of Some Puerto Rican Disonychina and Oedionychina (Coleoptera: Chrysomelidae: Alticinae: Oedionychini): Evolutionary Implications. Psyche 98(4):373-395. (Errata 99:140.)

Virkki, N., J. A. Santiago-Blay and E. G. Riley, 1992. Chromosomes of Puerto Rican Hispinae and Cassidinae (Coleoptera: Chrysomelidae). Coleops. Bull. 46:29-42.

Virkki, N. and J. A. Santiago-Blay, 1993. Trends of karyotype evolution in Neotropical Oedionychina (Coleoptera: Chrysomelidae: Alticinae). Hereditas 119:263-283.

Green, B., D. Wise and N. Virkki, 1993. Meiotic behavior of the sex chromosomes in spermatocytes of Alagoasa bicolor L. Molec. Biol. Cell 4:244.

Virkki, N. and T. Bruck, 1994. Unusually large sperm cells in Alticinae: Their formation and transportation in the male genital system, and their evolution. In: Novel aspects of the biology of Chrysomelidae, pp. 371-381. P. H. Jolivet, M. L. Cox and E. Petitpierre, (Eds.). Kluwer Acedemic Publishers, The Netherlands.

Virkki, N. and J. A. Santiago-Blay, 1994. Chromosomes of some Neotropical flea beetles (Coleoptera: Chrysomelidae: Alticinae) with inherently univalent, amphiorientating sex chromosomes and meioformula $11+\mathrm{X}+\mathrm{y}$ in the male meiosis. Cytobios 80:79-99.

Virkki, N. and J. A. Santiago-Blay, 1996. Chromosomes of some Puerto Rican flea beetles (Coleoptera: Chrysomelidae: Alticinae): multiple cytogenetic evolutionary tendencies in the neotropics. J. Zool. Syst. Evol. Res. 34:113-119.

Virkki, N. and J. A. Santiago-Blay, 1996. Atypical cytology in some Neotropical flea beetles (Coleoptera: Chrysomelidae: Alticinae: Oedionychina) from an intense natural radiation site known, Morro do Ferro (Brazil). Cytobios 85:167184. 
Santiago-Blay, J. A. and N. Virkki, 1996. Evolutionary relationships within Monoxia (Coleoptera: Chrysomelidae: Galerucinae): Chromosomal evidence for its intrageneric classification. Caryologia (Firenze, Italy) 49:257-265.

Virkki, N. and J. A. Santiago-Blay, 1997. Chromosomes of some Puerto Rican leaf beetles (Coleoptera, Chrysomelidae): biogeographical and evolutionary considerations. Cytobios 90:103-131.

Virkki, N. and C. W. O'Brien, 1997. Chromosome numbers of some brentid and curculionid weevils from Puerto Rico and the U.S. Virgin Islands. J. Agric. Univ. P.R. 81:191-201.

Virkki, N. and J. A. Santiago-Blay, 1998. Chromosome numbers in 71 Puerto Rican species of leaf beetles (Coleoptera: Chrysomelidae). J. Agric. Univ. P.R. 82:69-83.

Green-Marroquin, B. L, H. Kupfer, N. Virkki and D. A. Wise, 2001. Orientation of nonrandomly segregating sex chromosomes in spermatocytes of the flea beetle, Alagoasa bicolor L. Chromosoma 110:32-38.

\section{Species named in his honor:}

Ancyranoetus virkki Fain and Santiago-Blay 1993. Acarologia 34:339. (Acari: Histiostomatidae). Distribution: Puerto Rico.

Janbechynea (Bothroscelis) virkki Santiago-Blay 2004. In: New developments in the biology of Chrysomelidae. P. Jolivet, J. A. Santiago-Blay, and M. Schmitt (Editors). SPB Academic Publishers bv. The Hague, The Netherlands. 803 pp. 